\title{
Review on Marcuse's Theory of the Alienation of Science and Technology and Its Contemporary Values
}

\author{
Lu Qiuye \\ School of Marxism, Shenyang Jianzhu University \\ Shenyang, China, 110168 \\ 1257165739@qq.com
}

\author{
Ren Qiaohua \\ School of Marxism, Shenyang Jianzhu University \\ Shenyang, China, 110168 \\ Tony805@163.com
}

\begin{abstract}
Due to the development of the modern Enlightenment Movement, the capitalist industrial society is highly developed, and science and technology are alienated into a means of political rule. Alienated science and technology lead to the formation of a totalitarian society, which transforms the society into a unidimensional one, and makes people living in this society become unidimensional. It is Marcuse's philosophical reflection and criticism on the influence of the alienation of science and technology on politics, economy, culture and other fields that lead him to establish his theory of the alienation of science and technology. Studying Marcuse's theory of the alienation of science and technology will help us better understand and implement the goals set by the 19th CPC National Congress in establishing socialism with Chinese characteristics in the new era.
\end{abstract}

Keywords-Marcuse; the alienation of science and technology; unidimensional person; contemporary value

\section{INTRODUCTION}

Western Marxist schools, especially the Frankfurt school, have given in-depth and specific criticisms of the theory of the alienation of science and technology. Herbert Marcuse (July 19 1898-July 29, 1979) is a famous contemporary Jewish philosopher. He is the representative figure of the Institute of Frankfurt Social Studies - later known as the Frankfurt school. In his One-Dimensional Man, he criticized the capitalist society of political, economic, and cultural fields. In his opinion, scientific and technological advances have made the developed industrial society a new type of totalitarian society and formed a one-dimensional society. People living in the developed industrial societies have increasingly satisfied their false needs, and their critical and revolutionary characteristics have gradually diminished and became one-dimensional person. Through the review on the influencing factors, the main contents of the Marcuse's theory of the alienation of science and technology, and the problems caused by the alienation of science and technology, it is significant for China in the primary stage of socialism to understand the dialectical relationship between people and science and technology, material civilization and spiritual civilization, mass culture and advanced socialist cultures. It will be conducive to adhering to and developing socialism with Chinese characteristics in the new era.

\section{THE TRACEABILITY OF MARCUSE'S THEORY OF THE ALIENATION OF SCIENCE AND TECHNOLOGY}

\section{A. The Theory of labor Alienation of Marx}

In Manuscripts of Economics and Philosophy of 1844, Marx elaborately explored the theory of labor alienation and explicitly identified four provisions of alienated labor, namely, the alienation between laborer and labor product, the alienation between laborer and labor itself, the alienation between people and people, and the alienation between human own kind's essence and human beings. One of the provision-alienation between laborer and labor product expressed that the relationship between workers' own labor products and their labor is an alienated relationship. The performance of this alienation relationship is: "In capitalist society, because the products produced by workers are not owned by themselves, the larger scale of production and the more number of products produced by the workers, the greater the wealth of labor production and the greater the alien force, the more impoverished the workers."[1]Laborers produce the labor products, whereas labor products become the power to rule laborers. The labor products produced by the laborers themselves are opposed and separated from them. The greater the power created by the laborers to produce the products, the stronger the power to rule them, the less power the laborers will have, and ultimately lead to alienation between the laborers and labor products. Marx said: "The more a worker occupied the outside world and the sensible nature through his own labor, the more he lost his own labor object in the outside world, and lost the means to maintain his own and his family livelihood.'[2] Marx maintains that this is the inevitable result of private ownership.

Human labor is a kind of free, self-conscious, unconstrained, but under this crushing relationship of private ownership, workers do not willingly exert their own physical and spiritual power. However, in order to survive, workers only have to be serving as the slaves to means of production and products. Workers must be subject to the physical and mental destruction of the capitalist to obtain labor value. Workers 
constantly deny themselves rather than affirm their own labor in the process of labor. Workers feel that labor is not created by oneself, but oppressed. The result of labor is someone else. The nature of the alienation between laborer and labor is the alienation of human own kind's essence and the alienation between people and people, ultimately is the alienation of social relations. Marx's explanation of the alienation of labor itself and the alienation of human has exerted an important influence on Marcuse's alienation thought. In the study of Marx's alienation ideology, Marcuse absorbed Marx's alienation ideology and put forward the theory of the alienation of science and technology under the new conditions. $\mathrm{He}$ elaborated that in the high development of productive forces capitalist society, due to the alienation of science and technology, workers lose their freedom of choice and critical thinking. They become slaves to consumer products and become the one-dimensional man.

\section{B. The Theory of the Alienation of Science And Technology of Horkheimer}

M. Max Horkheimer is the founder and leader of the Frankfurt School. Horkheimer was committed to establishing "Critic Marxism" in his early years and proposed to recognize the criticism of Marxism together with Marcuse. In this process he organized his "Critic Marxism" system named "critical Marxist". In the period of exile, he made many unique analyses of capitalist society. His approaches to changing the capitalist society is carrying out the "social revolution", and fantasized about building a "managed world". [3]

In Horkheimer's view, today's society is in the transition from the existing ruling society to the "managed world" in the future. Human's progress, such as people's access to justice, equality, and satisfaction with material needs, is sacrificed at the expense of their humanity. Under the impetus of The Enlightenment, the rationality of bourgeois society has become instrumented. The practicalization and instrumentalization of science and technology has made science and technology become the tool of absolutism to rule human. The modern society formed by science and technology has depressed people's eros and led to the loss of human subjectivity and make people get into a new ignorance. Horkheimer sees science and technology as an ideology. It is precisely under the capitalist system that the ideology of science and technology awakens people to realize that the advancement of science and technology cannot achieve the objectives of the human essence, and makes people develop in every aspect with complete freedom.

Marcuse inherited Horkheimer's idea of science and technology, and combined Marx's theory of labor alienation with Horkheimer's theory of technological alienation. Marcuse insisted that science and technology itself and the alienation of science and technology are not necessarily linked, but that there is a problem with the organization of social labor. Marcuse further elaborated that the root of the alienation of science and technology attributed to the rationalization of instrumentalization, and argued that science and technology based on thinking manner of formal logic led to form the onedimensional society and one-dimensional man [4].

\section{THE CORE CONTENTS OF MARCUSE'S THEORY OF THE ALIENATION OF SCIENCE AND TECHNOLOGY}

\section{A. One-Dimensional Society}

The so-called one-dimensional society is the developed industrial society where the one-dimensional man is living. Marcuse believed that although the development of science and technology promotes the modern industrial society to enter the social stage of high production level and high consumption, it lost its inherent negation, thus forming a one-dimensional society. As a technological society, developed industrial society is a one-dimensional totalitarian society and is the final stage of achieving a special historical plan. In the political field, it has successfully achieved the goals of integrating political opposition. It means that society has only one voice, one will, no opposition, and all the parties are the same point of view. The relationship between the ruler and the ruled has lost the personality connection. Marcuse proposed the concept of "onedimensional society" when criticizing advanced industrial societies. The implication is that in the advanced modern industrial society, the entire society has only one kind of value orientation and a criterion for judgment. The developed capitalist industrial society has already become a onedimensional society rather than a multidimensional society. This is an inherent feature of the developed industrial society. In the way of life, the advanced science and technology of the developed industrial society has narrowed the difference in lifestyles between people and people. Because of the assimilation of lifestyles, people live in the same way and buy the same things produced by the capitalists. People will be satisfied with the existing way of life, and thus they believe that there will no longer be the class differences in their thoughts and will accept and no longer deny this society. The one-dimensional society also shows a single business culture in the cultural field. Marcuse stated clearly that high-level culture is an ideal and transcendental culture, which is higher than reality, alienated from reality, and criticizes society. Due to the advancement of science and technology, the high-level culture is unified with the realistic culture, and the high-level culture reduces to the commercial culture. "The cultural center has become a commercial center, a government center or a municipal center."[4]The image of rebellion in early literary works was conquered. The characters in contemporary literature are not pursuing another way of life. It can be said that in a one-dimensional society, people's ideals are surpassed by reality and people's ideology only exist the dimension of obedience It should be said that the emergence of many people who only possess "one-dimensional" in their ideological consciousness is the primary manifestation of the onedimensional society. 


\section{B. One-Dimensional Man}

The concept of the One-Dimensional Man was first proposed by Marcuse, known as the representative of Frankfurt School. In the book One-Dimensional Man, Marcuse gives a detailed account of the influence on people of the alienation of science and technology [4]. Marcuse indicates that normal people have two dimensions. The first is that people accept the reality of the reality of survive, and the second is that people criticize or even deny the reality of the existence of society. The concept of one-dimensional man refers to the fact that under the influence of the highly developed industrial society and the alienation of science and technology, people lose their ability to discriminate against the surrounding world and lose their second dimension of criticalness, negativity, and creativity. There remained only the first dimension of acceptance, obedience, affirmation, and satisfaction with the status quo. The inherent truth, goodness, beauty, selfknowledge, and the ability to transcend reality will also be lost.

Marcuse argues that in this highly developed capitalist society, as people's living conditions improve, physical labor decreases, consumer goods gradually increase, and production levels, science and technology, and lifestyles are more and more advanced. The richness of the society can meet the needs of citizens. People are increasingly adapting to this capitalist society and are not considering and reflecting on another way of life [5]. "When a society seems to be able to satisfy its individual needs more and more in accordance with its own organizational approach, independent thinking, freedom of the will and politics, the basic critical function of the right of opposing is gradually being deprived.'[4]In fact, this totalitarian society has suppressed the critical and negative way of thinking in human personality, and people have become a passive tool and the slaves of the production machinery and become a one-dimensional man.

\section{THE CONTEMPORARY VALUES OF MARCUSE'S THEORY OF THE ALIENATION OF SCIENCE AND TECHNOLOGY}

The original aspiration and the mission of Chinese Communists is to seek happiness for the Chinese people and rejuvenation for the Chinese nation. For the people's longing for a better life, Xi Jinping, General Secretary of China, pointed out in the report of the 19th National Congress of the Communist Party of China: "In the first stage from 2020 to 2035, we will build on the foundation created by the moderately prosperous society with a further 15 years of hard work to see that socialist modernization is basically realized. In the second stage from 2035 to the middle of the 21 st century, we will, building on having basically achieved modernization, work hard for a further 15 years and develop China into a great modern socialist country that is prosperous, strong, democratic, culturally advanced, harmonious, and beautiful.'[6]. In the process of achieving "The Two Centenary Goals", a series of problems that have arisen in the course of modernization in the Western developed capitalist countries, in particular Marcuse's theory of political, economic, cultural, and scientific and technological alienation of capitalist society, as well as the criticism of one-dimensional society and one-dimensional man, have a certain significance for our understanding the Western advanced capitalist society, the promotion of scientific and technological progress, the promotion of all-round development of human beings, and upholding and developing socialism with Chinese characteristics in a new era.

\section{A. View the Development of Science and Technology Dialectically}

As an important symbol of advanced productive forces, science and technology plays an important role in promoting social development and human development. The rapid advancement of modern science and technology has promoted the great development of the world's productive forces, and has also promoted the improvement of people's living standards and quality of life, bringing tremendous material wealth to humankind, but science and technology is two sides sword. It is also undeniable that various negative issues brought about by the highly developed science and technology, Marcuse's critique of science and technology in the developed western industrial society is enough to make us sound the alarm. The 19th National Congress of the Communist Party of China explicit that with decades of hard work, socialism with Chinese characteristics has crossed the threshold into a new era [6]. The innovative development of science and technology plays an extremely important role in securing a decisive victory in building a moderately prosperous society in all respects, and of moving on to all-out efforts to build a great modern socialist country. How to make science and technology develop steadily and healthily, benefit humanity and avoid the phenomenon of the alienation phenomenon that Marcuse criticized become issues that we must be aware of. We must correctly understand and treat science and technology. We should realize that science and technology are used by human beings. They are controlled by human beings, not the tools of ruling human. Only in this way can the value of science and technology be brought into play for our society and contribute to the socialist modernization.

\section{B. Adhere to the Coordinated Development of Material Civilization and Spiritual Civilization}

Marcuse states in his One-Dimensional Man that the highly advanced science and technology have greatly enriched the material wealth of society, but people's spiritual life is scarce, people are vilified by things, and things become the spiritual ties of people [4]. Although Marcuse completely attributed the human spiritual suffering to the great enrichment of material wealth and the high degree of development of productivity is absolute and one-sided. However, he proposed that in the high development of things, we must pay attention to the existence and development of human beings. People will not be exposed to the phenomenon of material abundance and spiritual misery in the pursuit of material life. It has implications for solving the imbalances and inadequate problems that arise in China's development and adhering to commitment to our peoplecentered philosophy of development. As socialism with Chinese characteristics has entered a new era, the principal contradiction facing Chinese society has evolved. What we now face is the contradiction between unbalanced and inadequate development and the people's ever-growing needs for a better life [6]. Therefore, in the process of socialist modernization, while satisfying people's material and cultural needs, we must also allow people to enjoy a highly developed 
spiritual life. We must adhere to the commitment to our people-centered philosophy of development as the important content of a new era to uphold and develop Chinese characteristics of socialism. Adhering to the people's dominant status and the free and comprehensive development, vigorously strengthen the building of socialist spiritual civilization, and enable material civilization and spiritual civilization to develop in a coordinated manner.

\section{Strengthen Cultural Self-Confidence and Promote Socialist Culture Prosperity}

Marcuse's critique of the commercialization of western capitalist society and culture suggest that science and technology make culture become a commodity and subject to market rules and value rules, losing its original artistic and autonomous values. Marcuse's critical theory of culture has a certain value for building a culturally strong country. The birth of mass culture is a kind of cultural consumption phenomenon produced by the rapid development of modern industrial society and the market economy. It is accepted by the masses for its universality, richness, and easiness of dissemination. The mass culture in our country has its own development law and its own special aspects. Therefore, through Marcuse's critical theory of culture, we must recognize the historical and environmental differences between Chinese and Western cultures, and we must make full use of our mass culture for promoting social development and constructing traditional cultural pattern. We should fully manifest the positive value of mass culture and also recognize a series of problems that arise when mass culture becomes a commercial culture and follows the law of market value development. We should integrate the mass culture with the advanced cultures of socialism. With the guidance of the socialist core values, we solidly promote the construction of a culturally strong country [7].

\section{CONCLUSION}

In the 21st Century, under the new historical conditions, the status of science and technology in the development of human society has been continuously increasing, which has contributed to the continuous progress of modern industrial society. At the same time, a series of negative effects are bringing about by science and technology gradually emerged. Marcuse inherited Marx's theory of labor alienation and Horkheimer's view of science and technology, and put forward the idea of the alienation of science and technology in his books such as One-Dimensional Man and An Essay on Liberation. He claimed that science and technology in the capitalist society did not play its own positive role, but gradually ideological [8]. The society has become a totalitarian society, that is, a one-dimensional society. This society has suppressed people's thinking and caused people to lose their critical and negation. People has become a one-dimensional man.
Marcuse's theory of the alienation of science and technology provides a new ideological dimension for how we use science and technology today and how to coordinate the relationship between people and science and technology and between people and society. In the process of modernization, Marcuse's theory of the alienation of science and technology also has certain referential significance for how we look at social development and how to make human freedom and allaround development. However, Marcuse's theory of the alienation of science and technology has certain limitations. Marcuse did not see the essence of modern capitalist society and the real cause of the malady of capitalism is the institutional problem of capitalism. He only used two means of cultural criticism and ideological criticism, rather than exposing the essence of modern capitalist society as Marx did, used plutonomy as a means of critique. In the end, Marcuse has a very pessimistic attitude toward the prospects of proletarian revolution and human liberation, and his theory of the alienation of science and technology is bound to have limitations.

\section{ACKNOWLEDGMENT}

This paper is sponsored by Projects of the National Social Science Foundation of China (15CZX014), "EEM Program's Theoretical Development and Methodological implications".

\section{REFERENCES}

[1] Karl Marx and Frederick Engels: Vol.42 [M]. Beijing: People's Publishing House, 2006:90.

[2] Karl Marx. Manuscripts of Economics and Philosophy of 1844 [M]. Beijing: People's Publishing House, 1979:49

[3] He Baofeng, Yang Hanxu. The Dual Dimension of Horkheimer's Critical Theory [J]. Hubei Social Sciences, 2013(03):109-112. (In Chinese)

[4] Herbert Marcuse. One-dimensional man: Studies in the ideology of advanced industrial society [M]. Boston: Beacon Press, 1964: 5, 206, 205, 3, 6 .

[5] Rainer Winter. One-Dimensionality and the Possibility of Utopia. The Contribution of Herbert Marcuse to a Transformation of the Present [J]. Journal of Literature and Art Studies, April 2017, Vol.7, No.4, 470-479

[6] Transformation of the Present [J]. Journal of Literature and Art Studies, April 2017, Vol.7, No.4, 470-479

[7] Xi Jinping. Secure a Decisive Victory in Building a Moderately Prosperous Society in All Respects, Strive for the Great Success of Socialism with Chinese Characteristics for A New Era-The Report of the 19th National Congress of the Communist Party of China(October 18, 2017)[M].Beijing: People's Publishing House,2017. (In Chinese)

[8] Yang Liwei, Bao Guoxiang. On the Enlightenment of Marcuse's Critical Theory on localization of Marxism in China [J]. Journal of Inner Mongolia University for the Nationalities. (Social Science Edition), 2013, 39(02):68-70. (In Chinese)

[9] Deng Wenfei, Tan Touhong. A Comparative Study of Ideological Theory between Marx and Marcuse [J]. Journal of Hunan First Normal University, 2008(01): 85-87. (In Chinese) 